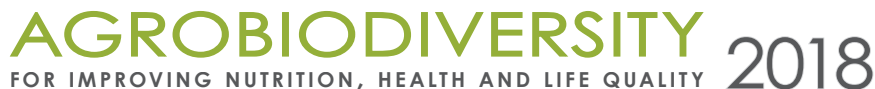

(웅

\section{OXIDATIVE STRESS BIOMARKERS IN THE MUSCLE TISSUE OF THE RAINBOW TROUT (ONCORHYNCHUS MYKISS WALBAUM) AFTER IN VITRO TREATMENT OF SANSEVIERIA CAULESCENS N.E.BR. EXTRACT}

\author{
Maryniuk Myroslava ${ }^{1}$, Tkachenko Halyna*2 ${ }^{2}$, Buyun Lyudmyla ${ }^{1}$, \\ Kharchenko Igor ${ }^{1}$, Osadowski Zbigniew ${ }^{2}$ \\ ${ }^{1}$ M.M. Gryshko National Botanic Garden, National Academy of Science of Ukraine, Kyiv, Ukraine \\ ${ }^{2}$ Institute of Biology and Environmental Protection, Pomeranian University in Słupsk, Poland
}

\section{Received: 29. 10. $2018 \quad$ Revised: 30. 10. $2018 \quad$ Published: 10. 12. 2018}

The goal of this study was to assess in vitro the effect of buffer extract obtained from leaves of Sansevieria caulescens N.E.Br. on the 2-thiobarbituric acid reactive substances (TBARS) as lipid peroxidation biomarker, aldehydic and ketonic derivatives of oxidatively modified proteins, and total antioxidant capacity (TAC) in the muscle tissue of the rainbow trout. Our study suggests that the leaf S. caulescens extract have shown good antioxidant potential in vitro study after incubation with muscle tissue homogenate of rainbow trout. There were no significant changes for TBARS level as biomarker of lipid peroxidation, aldehydic and ketonic derivatives of oxidatively modified proteins between values in control group and in the muscle tissue of rainbow trout after incubation with extracts from leaves of $S$. caulescens. Our results showed that extract of $S$. caulescens efficiently increased the total antioxidant capacity in muscle tissue by $46.6 \%(p<0.05)$ due to inhibited the $\mathrm{Fe}^{2+} /$ ascorbate-induced oxidation of Tween 80, resulting in a decrease in the TBARS level. Taking into account existing experimental evidence, it is reasonable to assume that secondary plant metabolites, i.e. polyphenolic compounds in the extract of $S$. caulescens may contribute to the antioxidant activity. Further studies including both the use of other medicinal plants as food additives in aquaculture and the assessment of its antioxidant effects on various tissues are in progress.

Keywords: rainbow trout (Oncorhynchus mykiss), Sansevieria caulescens N.E.Br., 2-thiobarbituric acid reactive substances (TBARS), aldehydic and ketonic derivatives of oxidatively modified proteins, total antioxidant capacity

\section{Introduction}

The fishery is a source of income and social development, particularly in developing countries, playing a great role in food security and livelihood (FAO, 2016). Huge loss of production in aquaculture is occurring because of many reasons. Studies showed that almost fifty percent of

\footnotetext{
*Corresponding author: Halyna Tkachenko, Institute of Biology and Environmental Protection, Pomeranian University in Słupsk, Arciszewski Str. 22b, 76-200 Słupsk, Poland; $\triangle$ tkachenko@apsl.edu.pl
} 
production loss is because of diseases which are more severe in developing countries (Assefa et al., 2018). In recent years, to develop the alternative practices for disease management in aquaculture, attention was diverted to find novel drugs. Biological and chemical disease control strategies such as using probiotics, prebiotics, and medicinal plants are widely in use. Plant product application in aquaculture for disease control is one of the promising alternatives to antibiotics (Assefa et al., 2018). Plant-derived compounds act as a better antibacterial, antiviral, immunostimulant and antistress effect in fish and shellfish aquaculture (Anusha et al., 2014). Use of herbal therapy within animal production, as well as in the diet of commercial fishes has shown promise, in that it is natural and biodegradable and has antimicrobial activity against various pathogens, including those relating to fish (Valladão et al., 2015). The herbals having the characteristics of immunostimulants been able to increase the survival and reduce the pathogenic load against pathogenic challenge by improving the immune system in fishes (Anusha et al., 2014). On the other hand, many plant-derived compounds and medicinal plant products have been found to have non-specific immunostimulating properties in animals, of which more than a dozen have been evaluated in fin and shellfishes and, specifically, to prevent and control fish diseases (Galina et al., 2009). However, applying a new component as a drug in the fish diet requires more research on the effects on the physiological and health status of animals. Undoubtedly, a healthy diet is an important factor in the prevention of widespread various diseases in aquaculture. Therefore, the study of diet components such as dietary supplements, particularly drugs, is essential (Banaee et al., 2011).

Considering that almost all fish produced from aquaculture is for human consumption, residual drugs in fish products can affect people who consume them, and antimicrobials released into aquatic environments can select for resistant bacteria. Moreover, these antimicrobial-resistant bacteria, or their resistance genes, can be transferred to humans (Park et al., 2012).

In this study, attention was focused on Sansevieria Thunb., a genus with diverse ethnobotanical uses in its geographical distribution range, which occupies an important place among plant genera applied for treatment of a broad spectrum of diseases and disorders (Watt and BreyerBrandwijk, 1962; Chhabra et al., 1987; Khalumba et al., 2005; Staples and Herbst, 2005; Kiringe, 2006; Owuor and Kisangau, 2006; Takawira-Nyenya et al., 2014). Our previous study (Buyun et al., 2016; Tkachenko et al., 2017) have highlighted the antibacterial capacity of ten species of Sansevieria genus against Staphylococcus aureus. These plants have been screened in order to validate scientifically the inhibitory activity for microbial growth attributed to their popular use and to propose new sources of antimicrobial agents. The leaves of Sansevieria canaliculata Carrière, S. trifasciata Prain, S. cylindrica Bojer ex Hook., S. parva N.E.Br. (syn. S. dooneri N.E.Br.), S. fischeri (Baker) Marais, S. kirkii Baker, S. aethiopica Thunb., S. metallica Gérôme \& Labroy, S. caulescens N.E.Br., S. francisii Chahin were used. Our results proved that the zones of inhibition ranged from 16 to $34 \mathrm{~mm}$. Extracts from the leaves of $S$. fischeri and S. francisii were particularly active against tested organism (inhibition zones comprise up to $34 \mathrm{~mm}$ in diameter). This was followed by the activities of extracts from the S. parva, S. kirkii, S. aethiopica, S. caulescens, S. metallica leaves (diameters of inhibition zones ranged from 25 to $31 \mathrm{~mm}$ ). The ethanolic extracts of $S$. canaliculata and $S$. trifasciata showed less antimicrobial activities (diameters of inhibition zones ranged between 16 and $16.5 \mathrm{~mm}$ ). The results 
proved that the ethanolic extracts from S. fischeri, S. francisii, S. parva, S. kirkii, S. aethiopica, S. caulescens, $S$. metallica exhibit a favorable antibacterial activity against $S$. aureus (Buyun et al., 2016; Tkachenko et al., 2017).

In our previous study, we also studied the antioxidant activity of extracts obtained from leaves of selected species from Sansevieria species against oxidative stress using equine erythrocyte suspension (Tkachenko et al., 2017). When erythrocytes were incubated with leaf extracts of various species from Sansevieria genus, the aldehydic derivatives level was significantly reduced by $13.6 \%(p<0.05)$ for $S$. forskaliana extract. Moreover, all extracts (except $S$. francisii extract) reduced the formation of intracellular aldehydic derivatives of oxidatively modified proteins (OMP) in the extracts-treated erythrocytes, but these results were non-significant. Treatment by extracts of various Sansevieria species reduced the concentration of ketonic derivatives of OMP when compared to untreated erythrocytes. The most potent effect was demonstrated by the S. canaliculata, S. forskaliana, S. aethiopica, S. cylindrica, S. metallica, S. hyacinthoides, and S. kirkii compared to control samples (phosphate buffer) $(16.1,14.7,13.4,12.9,12.9,12.7,12.1 \%$, respectively). However, there were no significant changes in other extracts. The experimental evidence obtained in our previous study indicated that various species of Sansevieria genus are a rich source of compounds that manifest antioxidant activity and can effectively protect erythrocytes against oxidative-induced damage. Thus, S. canaliculata, S. forskaliana, S. aethiopica, S. cylindrica, S. metallica, S. hyacinthoides, and S. kirkii may be a valuable source of natural antioxidants that may potentially be recommended for applications in medicine and veterinary practice. According to the above-mentioned antioxidant mechanisms, extracts of various species from Sansevieria genus may inhibit the formation of protein carbonyl by scavenging free radicals formed in vitro. According to many supporting documents, it can be assumed that secondary plant metabolites, i.e. polyphenolic compounds in extracts of various species from Sansevieria genus extract may contribute to the antioxidant activity (Tkachenko et al., 2017).

Although antimicrobial activities of extracts obtained from the leaves of various species of Sansevieria genus were investigated so far (Aliero et al., 2008; Sheela et al., 2012; Kingsley et al., 2013; Buyun et al., 2016, 2017; Tkachenko et al., 2017), there is still much work to do, because studies regarding their total antioxidant defences as well as assessment of marker of lipid peroxidation under in vitro incubation with the muscle tissue of the rainbow trout (Oncorhynchus mykiss Walbaum) have not been undertaken yet.

Consequently, the aim of this study was to evaluate in vitro the effect of buffer extract obtained from leaves of Sansevieria caulescens on the 2-thiobarbituric acid reactive substances (TBARS) as lipid peroxidation biomarker, aldehydic and ketonic derivatives of oxidatively modified proteins, and total antioxidant capacity in the muscle tissue of the rainbow trout.

\section{Materials and methodology}

\section{Collection of plant material}

The leaves of Sansevieria caulescens plants, cultivated under glasshouse conditions, were sampled at M.M. Gryshko National Botanic Garden (NBG), National Academy of Science of Ukraine (Figure 1). 


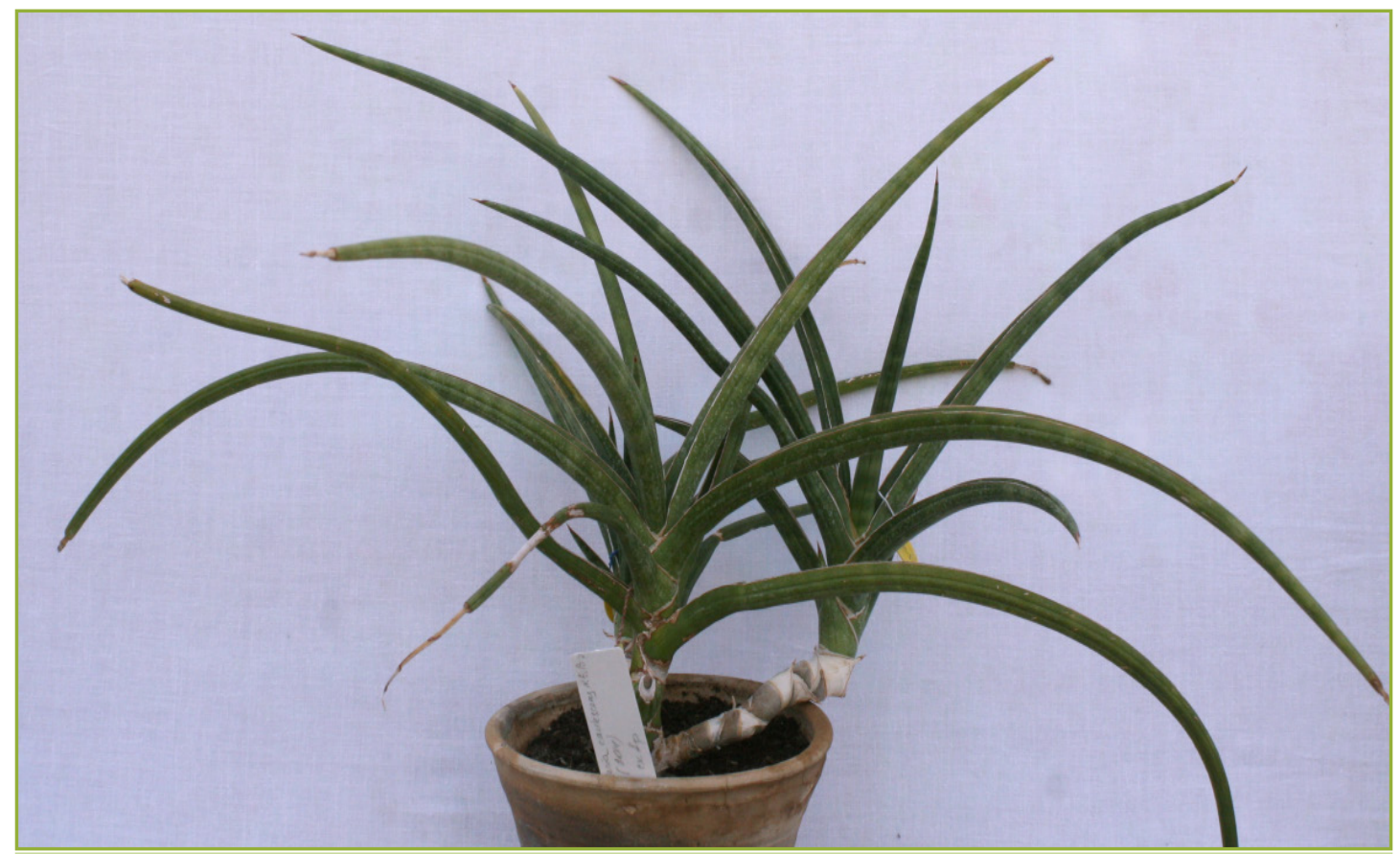

Figure 1 General view of Sansevieria caulescens N.E.Br. plant (Photo by Myroslava Maryniuk)

\section{Preparation of plant extract}

Freshly collected leaves were washed, weighted, crushed, and homogenized in $0.1 \mathrm{M}$ phosphate buffer (pH 7.4) (in proportion $1: 19, \mathrm{w} / \mathrm{w}$ ) at room temperature. The extract was then filtered and investigated for its antioxidant capacity. The extract was stored at $-20^{\circ} \mathrm{C}$ until use.

\section{Experimental fish}

Clinically healthy rainbow trout with a mean body mass of $80-120 \mathrm{~g}$ were used in the experiments. The experiments were performed in water at $14.5 \pm 0.5^{\circ} \mathrm{C}$ and $\mathrm{pH} 7.2-7.4$. The dissolved oxygen level was about $9 \mathrm{ppm}$ with additional oxygen supply, with a water flow

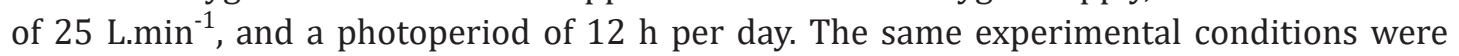
used during the whole research. The water parameters were maintained under constant surveillance. The fish were held in square tanks (150 fish per tank) and fed commercial pelleted diet.

\section{Muscle tissue samples}

The muscle tissue samples were homogenized in ice-cold buffer (100 mM Tris-HCl, pH 7.2) using a glass homogenizer immersed in an ice water bath. Homogenates were centrifuged at $3000 \mathrm{~g}$ for $15 \mathrm{~min}$ at $4{ }^{\circ} \mathrm{C}$. After centrifugation, the supernatant was collected and frozen at $-20{ }^{\circ} \mathrm{C}$ until analyzed. All enzymatic assays were carried out at $22 \pm 0.5^{\circ} \mathrm{C}$ using a Specol 11 spectrophotometer (Carl Zeiss Jena, Germany) in duplicate. The reactions were started by adding the tissue supernatant. 


\section{Experimental design}

The supernatant of the muscle tissue was used to incubate with $S$. caulescens extract (in a ratio of $19: 1$ ) at room temperature. The control group (trout muscle tissue) was incubated with 100 mM Tris-HCl buffer (pH 7.2) (in a ratio 19:1). The incubation time was 2 hours. Oxidative stress biomarkers were studied in the incubated homogenate (control group and in samples with extract).

\section{Determination of 2-thiobarbituric acid reactive substances (TBARS)}

The level of lipid peroxidation was determined by quantifying the concentration of TBARS by Kamyshnikov (2004) for determining the malonic dialdehyde (MDA) concentration. Briefly, $2.1 \mathrm{~mL}$ of sample homogenate was added to $1 \mathrm{~mL}$ of $0.8 \%$ of 2 -thiobarbituric acid (TBA), and $1 \mathrm{~mL}$ of $20 \%$ of trichloroacetic acid (TCA). The mixture was heated in a boiling water bath for $10 \mathrm{~min}$. After cooling, the mixture was centrifuged at $3000 \mathrm{~g}$ for $10 \mathrm{~min}$. The absorbance of the supernatant was measured at $540 \mathrm{~nm}$. The concentration of MDA (nmol. $\mathrm{mg}^{-1}$ of protein) was calculated using $1.5610^{5} \mathrm{mM}^{-1} \mathrm{~cm}^{-1}$ as the extinction coefficient.

\section{The carbonyl derivatives content of protein oxidative modification (OMP) assay}

To evaluate the protective effects of the extract against free radical-induced protein damage, a carbonyl derivatives content of protein oxidative modification (OMP) assay based on the spectrophotometric measurement of aldehydic and ketonic derivatives in the samples was performed. The rate of protein oxidative destruction was estimated from the reaction of the resultant carbonyl derivatives of amino acid reaction with 2,4-dinitrophenylhydrazine (DNFH) as described by Levine and co-workers (1990) and as modified by Dubinina and co-workers (1995). DNFH was used for determining carbonyl content in soluble and insoluble proteins. Briefly, $1 \mathrm{~mL}$ of $0.1 \mathrm{M} \mathrm{DNPH}$ (dissolved in $2 \mathrm{M} \mathrm{HCl}$ ) was added to $0.1 \mathrm{~mL}$ of the sample after denaturation of proteins by $20 \%$ trichloroacetic acid (TCA). After addition of the DNPH solution (or $2 \mathrm{M} \mathrm{HCl}$ to the blanks), the tubes were incubated for a period of $1 \mathrm{~h}$ at $37^{\circ} \mathrm{C}$. The tubes were spun in a centrifuge for $20 \mathrm{~min}$ at $3000 \mathrm{~g}$. After centrifugation, the supernatant was decanted and $1 \mathrm{~mL}$ of ethanol-ethylacetate solution was added to each tube. Following the mechanical disruption of the pellet, the tubes were allowed to stand for 10 min and then spun again (20 min at $3000 \mathrm{~g}$ ). The supernatant was decanted and the pellet washed thrice with ethanol-ethylacetate. After the final wash, the protein was solubilized in $2.5 \mathrm{~mL}$ of $8 \mathrm{M}$ urea solution. To speed up the solubilization process, the samples were incubated in a $90{ }^{\circ} \mathrm{C}$ water bath for 10-15 min. The final solution was centrifuged to remove any insoluble material. The carbonyl content was calculated from the absorbance measurement at $370 \mathrm{~nm}$ and $430 \mathrm{~nm}$, and an absorption coefficient $22.000 \mathrm{M}^{-1} \cdot \mathrm{cm}^{-1}$. Carbonyl groups (nmol per $\mathrm{mg}$ of protein) were determined spectrophotometrically from the difference in absorbance at $370 \mathrm{~nm}$ (aldehyde derivatives, $\mathrm{OMP}_{370}$ ) and $430 \mathrm{~nm}$ (ketonic derivatives, $\mathrm{OMP}_{430}$ ).

\section{Measurement of total antioxidant capacity (TAC)}

The TAC level in the sample was estimated by measuring the 2-thiobarbituric acid reactive substances (TBARS) level after Tween 80 oxidation. This level was determined spectrophotometrically at $532 \mathrm{~nm}$ (Galaktionova et al., 1998). Sample inhibits the $\mathrm{Fe}^{2+} /$ 
ascorbate-induced oxidation of Tween 80 , resulting in a decrease in the TBARS level. Briefly, $0.1 \mathrm{~mL}$ of sample was added to $2 \mathrm{~mL}$ of $1 \%$ Tween 80 reagent, $0.2 \mathrm{~mL}$ of $1 \mathrm{mM} \mathrm{FeSO}$, and $0.2 \mathrm{~mL}$ of $10 \mathrm{mM}$ ascorbic acid. In the blank assay, $0.1 \mathrm{~mL}$ of distilled water was used instead of the sample. The mixture was heated in a water bath for $48 \mathrm{hrs}$ at $37^{\circ} \mathrm{C}$. After cooling, $1 \mathrm{~mL}$ of $20 \%$ trichloroacetic acid was added. The mixture was centrifuged at $3000 \mathrm{~g}$ for $10 \mathrm{~min}$. After centrifugation, $2 \mathrm{~mL}$ of supernatant and $2 \mathrm{~mL}$ of $0.25 \%$ 2-thiobarbituric acid were mixed. The mixture was heated in a water bath at $95{ }^{\circ} \mathrm{C}$ for $15 \mathrm{~min}$. The absorbance of the obtained solution was measured at $532 \mathrm{~nm}$. The absorbance of the blank was defined as $100 \%$. The level of TAC in the sample (\%) was calculated with respect to the absorbance of the blank sample.

\section{Statistical analysis}

The mean \pm S.E.M. values were calculated for each group to determine the significance of the intergroup difference. All variables were tested for normal distribution using the KolmogorovSmirnov and Lilliefors test $(p>0.05)$. The significance of differences (significance level, $p<0.05$ ) was examined using the Mann-Whitney $U$ test (Zar, 1999). All statistical calculation was performed on separate data from each individual with STATISTICA 8.0 software (StatSoft, Krakow, Poland).

\section{Results and discussion}

In a present study, we have studied the influence of extracts derived from leaves of $S$. caulescens on the TBARS level as biomarker of lipid peroxidation, aldehydic and ketonic derivatives of oxidatively modified proteins and the total antioxidant capacity in the muscle tissue of rainbow trout after incubation with extract obtained from leaves of $S$. caulescens in in vitro culture. There were no significant changes for TBARS level between the value in the control group and in the muscle tissue of rainbow trout after incubation with extracts derived from leaves of S. caulescens (Figure 2).

It is considered that disturbed levels of reactive oxygen species (ROS) contribute to the pathology of many disorders and diseases. ROS and oxidative stress may cause cellular damage by directly and irreversibly damaging macromolecules such as proteins, membrane lipids, and DNA; another major cellular consequence of reactive oxygen species is the reversible modification of protein thiol side chains that may affect many aspects of molecular function (Terrill et al., 2013). The redox dysregulation and ROS do not just beget further reactive species but also drive antioxidant protein expression. The redox-regulated antioxidant response offers the possibility of controlling the extent of ROS available to damage proteins and to restore the intracellular redox potential (Griffiths et al., 2014). In our study, the level of aldehydic and ketonic derivatives of oxidatively modified proteins was non-significantly changed in muscle samples incubated with an extract obtained from the leaves of S. caulescens (Figure 2).

The total antioxidant capacity (TAC) is determines the ability of a tested material to neutralize oxygen-free radical specific form, irrespectively to the specific antioxidant activity of present antioxidants (Wang et al., 1997). Our results showed that extract of $S$. caulescens efficiently 
increased the TAC level in muscle tissue by $46.6 \%(p<0.05)$ due to inhibited the $\mathrm{Fe}^{2+} /$ ascorbateinduced oxidation of Tween 80, resulting in a decrease in the TBARS level (Figure 2).

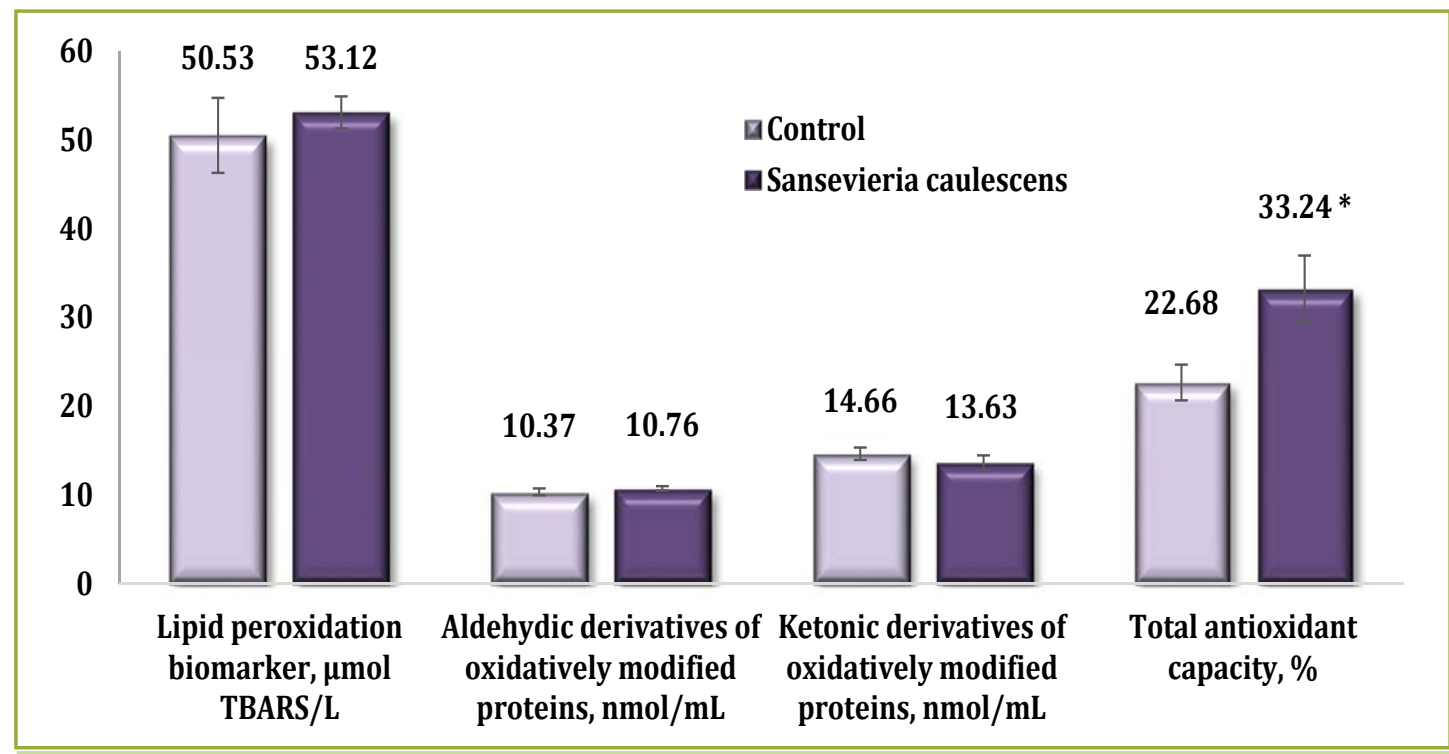

Figure 2 The level of 2-thiobarbituric acid reactive substances (TBARS), aldehydic and ketonic derivatives of oxidatively modified proteins and total antioxidant capacity in the muscle tissue of rainbow trout after incubation with extracts from leaves of Sansevieria caulescens $(M \pm \mathrm{m}, n=8)$

$*$ the changes are statistically significant $(p<0.05)$ compared to the control group

We suggested that high TAC value of muscle tissue is the result of a high content of by-products, i.e. alkaloids, flavonoids, saponins, glycosides, terpenoids, tannins, proteins, carbohydrates etc. in $S$. caulescens. The antioxidant activities of most plant extracts can be traced to these bioactive constituents. For instance, various compounds belonging to the terpenoid and flavonoid groups are known to be biologically active (Grassmann, 2005; González-Burgos and Gómez-Serranillos, 2012; Bartikova et al., 2014). Due to their antioxidant behaviour terpenes have been shown to provide relevant protection under oxidative stress conditions in different diseases including liver, renal, neurodegenerative and cardiovascular diseases, cancer, diabetes as well as in ageing processes (González-Burgos and Gómez-Serranillos, 2012). The existing data indicate that monoterpenes and diterpenes, which are the main components of essential oils, act as allelopathic agents, attractants in plant-plant or plant-pathogen/ herbivore interactions or repellants (Grassmann, 2005). Moreover, many sesquiterpenes biological activities (anti-inflammatory, antiparasitic and anti-carcinogenic activities) are based on antioxidant or pro-oxidant actions of sesquiterpenes. Structure, concentration, metabolism as well as the type of cells determine if sesquiterpene acts as anti-oxidant or pro-oxidant (Bartikova et al., 2014). On the other hand, the natural flavones, as well as some of their synthetic derivatives, have been shown to exhibit several biological activities, including antioxidant, anti-inflammatory, antitumor, anti-allergic, neuroprotective, cardioprotective and antimicrobial (Catarino et al., 2015). Also, flavonoids are found to have an effect on several 
mammalian enzymes like protein kinases that regulate multiple cell signalling pathways and alterations in multiple cellular signalling pathways are frequently found in many diseases (Singh et al., 2014). Some flavones interfere in distinct oxidative-stress related events by directly reducing the levels of intracellular free radicals (hydroxyl, superoxide and nitric oxide) and/or of reactive species (e.g. hydrogen peroxide, peroxynitrite and hypochlorous acid) thus preventing their amplification and the consequent damage of other biomolecules such as lipids, proteins and DNA (Catarino et al., 2015). Flavones and flavonols re-establish the redox regulation of proteins, transcription factors and signalling cascades that are otherwise inhibited by elevated oxidative stress (Dajas et al., 2013). Flavones can also hinder the activity of central free radical-producing enzymes, such as xanthine oxidase and nicotinamide adenine dinucleotide phosphate oxidase (NADPH-oxidase) or inducible nitric oxide synthase (iNOS) and can even modulate the intracellular levels of pro-oxidant and/or antioxidant enzymes (Catarino et al., 2015).

Indeed, the study of $S$. roxburghiana and $S$. trifasciata has revealed the presence of important compounds which were separated by thin layer chromatography (Kingsley et al., 2013). Preliminary phytochemical screening of the extracts of $S$. trifasciata plant showed the presence of alkaloids, flavonoids, saponins, glycosides, terpenoids, tannins, proteins and carbohydrates (Anbu et al., 2009). Additionally, the methanolic extract of the whole plant of S. trifasciata has yielded 12 steroidal saponins, 10 of which are new constituents (Mimaki et al., 1996). Phytochemical analysis of the whole plant of $S$. trifasciata has resulted in the isolation of four new pregnane glycosides (Mimaki et al., 1997). Gas chromatographic analysis of the leaves revealed the presence of alkaloids, allicins, glycosides, and saponins (Ikewuchi et al., 2011). Pettit et al. (2005) have isolated three new spirostanol saponins designated sansevierin A (1), sansevistatin 1 (2), and sansevistatin 2 (3) (10 $\%$ yield) from the $\mathrm{CH}_{3} \mathrm{OH}$ $\mathrm{CH}_{2} \mathrm{Cl}_{2}$ extract of $S$. ehrenbergii, accompanied by three known steroidal saponins (4-6), using bioactivity-directed isolation procedures. Each of the saponins was evaluated against the P388 lymphocytic leukemia cell line and a panel of human cancer cell lines. Except for 1 , all were found to cause inhibition of cancer cell growth. In addition, most of the saponins exhibited antimicrobial activity, particularly against the pathogenic fungi Candida albicans and Cryptococcus neoformans (Pettit et al., 2005). In addition, a new steroidal saponin from the leaves of S. cylindrica was isolated by Da Silva Antunes et al. (2003). The steroidal saponin showed no hemolytic effects in the in vitro assays and demonstrated inhibition of the capillary permeability activity (Da Silva Antunes et al., 2003). Accumulated evidence suggests that saponins have significant neuroprotective effects on attenuation of central nervous system disorders, such as stroke, Alzheimer's disease, Parkinson's disease, and Huntington's disease due to mechanisms of their neuroprotective function including antioxidant, modulation of neurotransmitters, anti-apoptosis, anti-inflammation, attenuating $\mathrm{Ca}^{2+}$ influx, modulating neurotrophic factors, inhibiting tau phosphorylation, and regeneration of neural networks (Sun et al., 2015).

Our study is in agreement with results obtained by other researchers. They have revealed hypoglycemic, hypolipidemic, immune-modulating, anti-inflammatory, ocular-, hepato-renal and cardio-protective potentials of other species of Sansevieria genus. Chigozie and Chidinma 
(2013) have investigated the ability of an aqueous extract of the leaves of S. liberica to alter the hematology, plasma biochemistry and ocular indices of oxidative stress in alloxan-induced diabetic rats. Diabetes mellitus was induced by injection of alloxan ( $80 \mathrm{mg}^{\mathrm{kg}} \mathrm{kg}^{-1}$ body weight), via the tail vein. The extract was administered orally at 100,200 and $300 \mathrm{mg}^{-\mathrm{kg}^{-1}}$ body weight (both to normal and diabetic rats), and metformin at $50 \mathrm{mg} \cdot \mathrm{kg}^{-1}$ body weight. Compared to test control, the treatment dose-dependently, significantly lowered $(p<0.05)$ ocular malondialdehyde content, atherogenic indices, red cell, total white cell and lymphocyte counts, mean cell hemoglobin concentration; and plasma levels of glucose, triglyceride, total-, very low density lipoprotein-, low density lipoprotein- and non-high density lipoprotein cholesterols, total, conjugated and unconjugated bilirubin, sodium, urea, blood urea nitrogen, as well as plasma activities of alkaline phosphatase, alanine and aspartate transaminases. However, the treatment significantly increased $(p<0.05)$ hematocrit, hemoglobin concentration, mean cell hemoglobin, and mean cell volume, neutrophil and monocyte counts, and plasma levels of high density lipoprotein cholesterol, potassium, chloride, calcium, bicarbonate and total protein, ocular ascorbic acid content and ocular activities of catalase and superoxide dismutase (Chigozie and Chidinma, 2013).

The leaves of S. liberica also possess anti-inflammatory effects. Chinasa et al. (2011) have evaluated the anti-inflammatory property of the leaves of S. liberica and to ascertain the toxicity and phytochemical profiles of the extract of the leaves. The crude extract was then fractionated into n-hexane fraction (HF), chloroform fraction (CF), ethyl acetate fraction (EF) and methanol fraction (MF). The crude extract and the fractions were screened for antiinflammatory activity using egg albumen-induced paw (systemic) edema in rats as a measure of acute inflammation. The crude extract and the fractions significantly $(p<0.05)$ inhibited the development of paw edema induced by egg albumen in rats. The potency/activity of the crude extract and the fractions increased in the order $\mathrm{HF}>\mathrm{CE}>\mathrm{MF}>\mathrm{CF}>\mathrm{EF}$, with the crude extract and $\mathrm{HF}$ at $400 \mathrm{mg} \cdot \mathrm{kg}^{-1}$ exhibiting inhibition comparable to that obtained with $5 \mathrm{mg} \cdot \mathrm{kg}^{-1}$ diclofenac sodium. Phytochemical screening of the crude extract and the fractions showed the presence of various bioactive substances such as alkaloids, saponins, flavonoids, terpenoids, steroids, glycosides, reducing sugars, tannins, resins, carbohydrates, proteins, acidic compounds, fats and oils (Chinasa et al., 2011).

The extract of the whole plant part of $S$. roxburghiana might possess some chemical constituents that are responsible for analgesic, cytotoxic and antioxidant activities. Roy et al. (2012) have investigated the crude methanolic extract of the whole plant part of $S$. roxburghiana and the possibility of analgesic, cytotoxic and antioxidant activities. The analgesic activity was assessed by acetic acid induced writhing test in mice. The cytotoxic activity was evaluated by brine shrimp lethality bioassay while the antioxidant effect was measured by 1, 1-diphenyl-2-picrylhydrazyl-hydrate (DPPH) free radical scavenging assay. The ethyl acetate soluble fraction of the crude extract was found to have significant $(p<0.001)$ analgesic activity at the oral dose of $100 \mathrm{mg} \cdot \mathrm{kg}^{-1}$ body weight. The crude methanolic extract along with its all partitions revealed mild to moderate free radical scavenging activity (Roy et al., 2012).

Oxidative stress is considered to be an important component of various diseases. Identifying markers of oxidative stress has been the focus of many researchers as they have the potential 
to act as an "integrator" of a multitude of processes that drive various kind of pathobiology (Ho et al., 2013). Therefore, in our opinion, any research assessing the biomarkers of oxidative stress has fundamental importance for the treatment of various diseases and disorders. On the other hand, plants with antioxidant potential may offer alternative therapeutic agents in the aquaculture industry.

\section{Conclusions}

Our study suggests that the $S$. caulescens leaf extract has shown good antioxidant potential in vitro study after incubation with muscle tissue homogenate of rainbow trout. There were no significant changes for TBARS level as biomarker of lipid peroxidation, aldehydic and ketonic derivatives of oxidatively modified proteins between values in control group and in the muscle tissue of rainbow trout after incubation with extracts from leaves of $S$. caulescens. Nevertheless, our results showed that extract of $S$. caulescens efficiently increased the total antioxidant capacity in muscle tissue by $46.6 \%(p<0.05)$ due to inhibited the $\mathrm{Fe}^{2+} /$ ascorbateinduced oxidation of Tween 80, resulting in a decrease in the TBARS level. Taking into account existing experimental evidence, it is reasonable to assume that secondary plant metabolites, i.e. polyphenolic compounds in the extract of $S$. caulescens may contribute to the antioxidant activity. In conclusion, the results of this study provide a new perspective on the use of various Sansevieria species as a medicinal plant to improve the antioxidant response of rainbow trout. Further studies including the use of other medicinal plants as food additives in aquaculture, the assessment of its antioxidant effects on various tissues are in progress. Finally, research needs to be focused on subjecting fish to these compounds to determine their effectiveness, stability, and impact both on the host and on the environment.

\section{Acknowledgement}

This study was carried out during Scholarship Program supported by The Polish National Commission for UNESCO in the Department of Zoology, Institute of Biology and Environmental Protection, Pomeranian University in Slupsk (Poland). We thank The Polish National Commission for UNESCO for the supporting our study.

\section{References}

ALIERO, A.A., JIMOH, F.O., AFOLAYAN, A.J. 2008. Antioxidant and antibacterial properties of Sansevieria hyacinthoides. In Int. J. Pure Applied Sci., vol. 2, p. 103-110.

ANBU, J.S., JAYARAJ, P., VARATHARAJAN, R., THOMAS, J., JISHA, J., MUTHAPPAN, M. 2009. Analgesic and antipyretic effects of Sansevieria trifasciata leaves. In Afr. J. Tradit. Complement. Altern. Med., vol. 6(4), p. 529-533.

ANUSHA, P., THANGAVIJI, V., VELMURUGAN, S., MiCHAELBABU, M., CITARASU, T. 2014. Protection of ornamental gold fish Carassius auratus against Aeromonas hydrophila by treating Ixora coccinea active principles. In Fish Shellfish Immunol., vol. 36(2), p. 485-493. http://dx.doi.org/10.1016/j. fsi.2013.12.006

ASSEFA, A., ABUNNA, F. 2018. Maintenance of fish health in aquaculture: review of epidemiological approaches for prevention and control of infectious disease of fish. In Veterinary Medicine International, vol. 2018, ID 5432497. http://dx.doi.org/10.1155/2018/5432497 
BANAEE, M., SUREDA, A., MIRVAGHEFI, A.R., RAFEI, G.R. 2011. Effects of long-term silymarin oral supplementation on the blood biochemical profile of rainbow trout (Oncorhynchus mykiss). In Fish Physiol. Biochem., vol. 37(4), p. 885-896. http://dx.doi.org/10.1007/s10695-011-9486-z

BARTIKOVA, H., HANUSOVA, V., SKALOVA, L., AMBROZ, M., BOUSOVA, I. 2014. Antioxidant, pro-oxidant and other biological activities of sesquiterpenes. In Curr. Top. Med. Chem., vol. 14(22), p. 24782494. http://dx.doi.org/10.2174/1568026614666141203120833

BUYUN, L., MARYNIUK, M., TKACHENKO, H., OSADOWSKI, Z. 2017. Antibacterial evaluation of an ethanolic extract from Sansevieria trifasciata Prain against Staphylococcus aureus. In Proceedings of the International Scientific and Practical Internet Conference "Problems and perspectives of modern agricultural science“. Mykolaiv: Mykolaiv SDDS IAZ, p. 88.

BUYUN, L., TKACHENKO, H., OSADOWSKI, Z., MARYNIUK, M. 2016. Antibacterial activity of certain Sansevieria species against Staphylococcus aureus. In Słupskie Prace Biologiczne, vol. 13, p. 19-36.

CATARINO, M.D., ALVES-SILVA, J.M., PEREIRA, O.R., CARDOSO, S.M. 2015. Antioxidant capacities of flavones and benefits in oxidative-stress related diseases. In Curr. Top. Med. Chem., vol. 15(2), p. 105-119. http://dx.doi.org/10.2174/1568026615666141209144506

CHHABRA, S.C., MAHUNNAH, R.L.A., MSHIU, E.N. 1987. Plants used in traditional medicine in Eastern Tanzania 1. Pteridophytes and Angiosperms (Acanthaceae to Canellaceae). In Journal of Ethnopharmacology, vol. 21(3), p. 253-277. http://dx.doi.org/10.1016/0378-8741(87)90103-6

CHIGOZIE, I.J., CHIDINMA, I.C. 2013. Positive moderation of the hematology, plasma biochemistry and ocular indices of oxidative stress in alloxan-induced diabetic rats, by an aqueous extract of the leaves of Sansevieria liberica Gerome and Labroy. In Asian Pac. J. Trop. Med., vol. 6(1), p. 27-36. http://dx.doi.org/10.1016/S1995-7645(12)60196-5

CHINASA, E.C., IFEOMA, I.A., OBODOIKE, E.C., CHHUKWUEMEKA, E.S. 2011. Evaluation of antiinflammatory property of the leaves of Sansevieria liberica Ger. and Labr. (fam: Dracaenaceae). In Asian Pac.J. Trop. Med., vol. 4(10), p. 791-795. http://dx.doi.org/10.1016/S1995-7645(11)60195-8

DA SILVA ANTUNES, A., DA SILVA, B.P., PARENTE, J.P., VALENTE, A.P. 2003. A new bioactive steroidal saponin from Sansevieria cylindrica. In Phytother. Res., vol. 17(2), p. 179-182. http://dx.doi. org/10.1002/ptr.1059

DAJAS, F., ANDRÉS, A.C., FLORENCIA, A., CAROLINA, E., FELICIA, R.M. 2013. Neuroprotective actions of flavones and flavonols: mechanisms and relationship to flavonoid structural features. In Cent. Nerv. Syst. Agents Med. Chem., vol. 13(1), p. 30-35. http://dx.doi.org/10.2174/1871524911313010005

DUBININA, E.E., BURMISTROV, S.O., KHODOV, D.A., POROTOV, I.G. 1995. Okislitelnaya modifikatsiya belkov syivorotki krovi cheloveka, metod ee opredeleniya [Oxidative modification of human serum proteins. A method of determining it]. In Voprosy Meditsinskoŭ Khimii, vol. 41(1), p. 24-26 (In Russian).

FAO. 2016. The State of World Fisheries and Aquaculture, Contributing to food security and nutrition for all, Food and Agriculture. Organization of the United Nations, Rome, Italy, 2016.

GALAKTIONOVA, L.P., MOLCHANOV, A.V., EL'CHANINOVA, S.A., VARSHAVSKIII, BLA. 1998. Sostoyanie perekisnogo okisleniya lipidov u bolnyih s yazvennoy boleznyu zheludka i dvenadtsatiperstnoy kishki [Lipid peroxidation in patients with gastric and duodenal ulcers]. In Klinicheskaia Labaratornaia Diagnostika, vol. 6, p. 10-14 (In Russian).

GALINA, J., YIN, G., ARDÓ, L., JENEY, Z. 2009. The use of immunostimulating herbs in fish. An overview of research. In Fish Physiol. Biochem., vol. 35(4), p. 669-676. http://dx.doi.org/10.1007/ s10695-009-9304-z

GONZÁLEZ-BURGOS, E., GÓMEZ-SERRANILLOS, M.P. 2012. Terpene compounds in nature: a review of their potential antioxidant activity. In Curr. Med. Chem., vol. 19(31), p. 5319-5341. http://dx.doi. org/10.2174/092986712803833335 
GRASSMANN, J. 2005. Terpenoids as plant antioxidant. In Vitam. Horm., vol. 72, p. 505-535. http:// dx.doi.org/10.1016/S0083-6729(05)72015-X

GRIFFITHS, H.R., DIAS, I.H., WILLETTS, R.S., DEVITT, A. 2014. Redox regulation of protein damage in plasma. In Redox Biol., vol. 2, p. 430-435. http://dx.doi.org/10.1016/j.redox.2014.01.010

HO, E., GALOUGAHI, K.K., LIU, C.C., BHINDI, R., FIGTREE, G.A. 2013. Biological markers of oxidative stress: Applications to cardiovascular research and practice. In Redox Biology, vol. 1(1), p. 483-491. http://dx.doi.org/10.1016/j.redox.2013.07.006

IKEWUCHI, C.C., IKEWUCHI, J.C., AYALOGU, E.O., ONYEIKE, E.N. 2011. Quantitative determination of alkaloid, allicin, glycoside and saponin constituents of the leaves of Sansevieria senegambica Baker by gas chromatography. In Res. J. Sci. Technol., vol. 3, p. 308-312.

KAMYSHNIKOV, V.S. 2004. Reference book on clinic and biochemical researches and laboratory diagnostics. MEDpress-inform, Moscow.

KHALUMBA, M.L., MBUGUA, P.K., KUNG'U, J.B. 2005. Uses and conservation of some highland species of the genus Sansevieria Thunb. in Kenya. In African Crop Science Conference Proceedings, vol. 7, p. 527-532.

KINGSLEY, D., CHAUHAN, R., SINHA, P., ABRAHAM, J. 2013. Screening and Characterization of Antimicrobial Agents from Sanseveria roxburghiana and Sansveria trifasiata. In Asian Journal of Plant Sciences, vol. 12(5), p. 224-227. http://dx.doi.org/10.3923/ajps.2013.224.227

KIRINGE, J.W. 2006. A survey of traditional health remedies used by the Maasai of Southern Kaijiado District, Kenya. In Ethnobotany Research and Applications, vol. 4, p. 61-73. http://dx.doi. org/10125/238

LEVINE, R.L., GARLAND, D., OLIVER, C.N., AMIC, A., CLIMENT, I., LENZ, A.G., AHN, B.W., SHALTIEL, S., STADTMAN E.R. 1990. Determination of carbonyl content in oxidatively modified proteins. In Methods in Enzymology, vol. 186, p. 464-478. http://dx.doi.org/10.1016/0076-6879(90)86141-H

MIMAKI, Y., INOUE, T., KURODA, M., SASHIDA, Y. 1996. Steroidal saponins from Sansevieria trifasciata. In Phytochemistry, vol. 43(6), p. 1325-1331. http://dx.doi.org/10.1016/S0031-9422(96)00397-4

MIMAKI, Y., INOUE, T., KURODA, M., SASHIDA, Y. 1997. Pregnane glycosides from Sansevieria trifasciata. In Phytochemistry, vol. 44(1), p. 107-111. http://dx.doi.org/10.1016/S0031-9422(96)00477-3

OWUOR, B.O., KISANGAU, D.P. 2006. Kenyan medicinal plants used as antivenin: A comparison of plant usage. In Journal of Ethnobiology and Ethnomedicine, vol. 2(7), p. 1-8. http://dx.doi. org/10.1186/1746-4269-2-7

PARK, Y.H., HWANG, S.Y., HONG, M.K., KWON, K.H. 2012. Use of antimicrobial agents in aquaculture. In Rev. Sci. Tech., vol. 31(1), p. 189-197.

PETTIT, G.R., ZHANG, Q., PINILLA, V., HOFFMANN, H., KNIGHT, J.C., DOUBEK, D.L., CHAPUIS, J.C., PETTIT, R.K., SCHMIDT, J.M. 2005. Antineoplastic agents. 534. isolation and structure of sansevistatins 1 and 2 from the African Sansevieria ehrenbergii. In J. Nat. Prod., vol. 68(5), p. 729-733. http:// dx.doi.org/10.1021/np040203r

ROY, J., KUDDUS, M., BEGUM, B., CHOUDHURY, H. 2012. Evaluation of analgesic, cytotoxic and antioxidant activities of Sansevieria roxburghiana Schult. and Schult. f. In Asian Pac. J. Trop. Med., vol. 2(2), s723-s726. http://dx.doi.org/10.1016/S2221-1691(12)60303-7

SHEELA, D.J., JEEVA, S., SHAMILA, I.M., LEKSHMI, C.J., BRINDHA, J.R. 2012. Antimicrobial activity and phytochemical analysis of Sanseiveria roxburghiana leaf. In Asian Journal of Plant Science and Research, vol. 2(1), p. 41-44.

SINGH, M., KAUR, M., SILAKARI, O. 2014. Flavones: An important scaffold for medicinal chemistry. In Eur. J. Med. Chem., vol. 84, p. 206-239. http://dx.doi.org/10.1016/j.ejmech.2014.07.013

STAPLES, G.W., HERBST, D.R. 2005. A Tropical Garden Flora: Plants cultivated in the Hawaiian Island and other tropical places. Bishop Museum Press, Honolulu, Hawaii. 
SUN, A., XU, X., LIN, J., CUI, X., XU, R. 2015. Neuroprotection by saponins. In Phytother. Res., vol. 29(2), p. 187-200. http://dx.doi.org/10.1002/ptr.5246

TAKAWIRA-NYENYA, T., NEWTON, L.E., WABUYELE, E., STEDJE, B. 2014. Ethnobotanical uses of Sansevieria Thunb. (Asparagaceae) in Coast Province of Kenya. In Ethnobotany Research and Application, vol. 12(1), p. 51-69. http://dx.doi.org/10.17348/era.12.0.051-069

TERRILL, J.R., RADLEY-CRABB, H.G., IWASAKI, T., LEMCKERT, F.A., ARTHUR, P.G., GROUNDS, M.D. 2013. Oxidative stress and pathology in muscular dystrophies: focus on protein thiol oxidation and dysferlinopathies. In FEBS J., vol. 280(17), p. 4149-4164. http://dx.doi.org/10.1111/febs.12142

TKACHENKO, H., BUYUN, L., OSADOWSKI, Z., MARYNIUK, M. 2017. The antibacterial screening of certain Sansevieria species against Escherichia coli strain. In Youth and Progress of Biology: Book of Abstracts of XIII International Scientific Conference for Students and Ph.D. Students (Lviv, 25-27 April 2017). Lviv, p. 220-221.

TKACHENKO, H., BUYUN, L., OSADOWSKI, Z., MARYNIUK, M. 2017. The antibacterial activity of certain Sansevieria Thunb. species against Escherichia coli. In Agrobiodiversity for improving nutrition, health, and life quality, vol. 1, p. 446-453. http://dx.doi.org/10.15414/ agrobiodiversity.2017.2585-8246.446-453

TKACHENKO, H., BUYUN, L., PAŻONTKA-LIPIŃSKI, P., WITASZEK, M., OSADOWSKI, Z. 2017. In vitro protective effect of extracts obtained from various Sansevieria species against oxidative damage of proteins in equine erythrocytes. In Słupskie Prace Biologiczne, vol. 14, p. 247-265.

TKACHENKO, H.M., BUYUN, L.I., OSADOWSKI, Z., MARYNIUK, M.M. 2017. In vitro antibacterial activity of ethanolic extracts from leaves of various Sansevieria species against Escherichia coli. In Proceedings of XII International Pirogov scientific medical conference of students and young scientists, Federal State Budget Educational Institution of Higher Education "N.I. Pirogov Russian National Research Medical University", March 17, 2017. Moscow, p. 295.

VALLADÃO, G.M., GALLANI, S.U., PILARSKI, F. 2015. Phytotherapy as an alternative for treating fish disease. In J. Vet. Pharmacol. Ther., vol. 38(5), p. 417-428. http://dx.doi.org/10.1111/jvp.12202

WANG, H., CAO, G., PRIOR, R.L. 1997. Oxygen radical absorbing capacity of anthocyanins. In J. Agric. Food Chem., vol. 45(2), p. 304-309. http://dx.doi.org/10.1021/jf960421t

WATT, J.M., BREYER-BRANDWIJK, M.G. 1962. The Medicinal and Poisonous Plants of Southern and Eastern Africa. E \& S Livingstone Ltd., Edinburgh, Scotland.

ZAR, J.H. 1999. Biostatistical Analysis. $4^{\text {th }}$ ed., Prentice-Hall Inc., Englewood Cliffs, New Jersey. 